\title{
BIBECHANA
}

A Multidisciplinary Journal of Science, Technology and Mathematics

ISSN 2091-0762 (online)

Journal homepage: http://nepjol.info/index.php/BIBECHANA

\section{Recent seismic status of Shillong Plateau, Northeast India}

\author{
Ananta Panthi ${ }^{*}$, H. N. Singh ${ }^{2}$ \\ ${ }^{1}$ Department of Physics, Butwal Multiple Campus, Butwal \\ ${ }^{2}$ Department of Geophysics, Banaras Hindu University, Varanasi, India \\ *Corresponding author: Email: apanthi@hotmail.com \\ Article history: Received 27 October, 2012; Accepted 8 November, 2012
}

\begin{abstract}
Seismic status of Shillong Plateau of Northeast India has been studied, considering spatial and temporal pattern of the region and using seismicity data for the period 1808-2008. Cutoff magnitude and b-value has been estimated using earthquake data for the period 1963-2008. Seismic activity is observed to be very feeble along the major faults of Shillong Plateau and strong activity is found to occur slightly away from these faults and confined within middle portion at two locations of the region. The temporal pattern shows that the region is due for great earthquake. Focal depth distribution of the events shows that all the events are intermediate depth (less than $70 \mathrm{~km}$ ).
\end{abstract}

Keywords: b-value; seismicity; faults; focal depth; temporal; spatial.

\section{Introduction}

The Shillong plateau is located between the Himalaya and Bengal basin. The Shillong plateau is known as detached area from Indian shield comprises the Archaean to Proterozoic gneisses and is covered by quartzite, grit and slates [1]. This plateau also consists of patchy remnants of a Tertiary cover and some unclassified crystalline rocks. The topography of Shillong plateau shows a criss- cross pattern of faults cutting the ancient rocks of the basement [2]. This plateau has pop-up structure since Pliocene because of the loads of Himalaya [3]. The Shillong plateau has experienced vertical uplift [4] and the upliftment is believed to be $\sim 1 \mathrm{~km}$ [3]. The Shillong plateau is mostly E-W trending hill. This region consists of several faults with three main directions of orientation i.e. NW-SE, NE-SW and N-S. The major faults are mapped in the Shillong Plateau region such as Dauki fault trending E-W to the south [2], Chedrang fault and Oldhan fault to the north, Kopili fault to the east and Dhubri and Tista fault to the west.

Shillong Plateau region is seismically active in Northeast India, where a great earthquake (1897) has occurred in the past. The region has been seismically very active from 1897 to 1930 during which one great earthquake (1897) and three large earthquakes with $7 \leq \mathrm{M} \leq 7.6(1918,1923$ and 1930) have rocked the region in just 33 years period (Table 3). Three of these earthquakes i.e. 1897, 1918 and 1923 are located in a straight line along $91^{\circ} \mathrm{E}$ almost in the middle of the plateau whereas 1930 earthquake occurred at a distance of about $1^{\circ}$ to the west of it. The remaining part of the region towards east has been devoid of such seismic hazards in the past. 


\section{Data analysis}

Seismicity data were compiled considering almost all the available earthquake catalogues such as National Earthquake Information Centre (NEIC- USGS), International Seismological Centre (ISC), Advanced National Seismic Systems (ANSS), Incorporated Research Institutions for Seismology (IRIS), National Oceanic Atmospheric Administration (NOAA) and other published records by Tandon and Srivastava [5], Chandra [6], Gupta et al. [7] etc. as sources of earthquakes. Using the earthquakes records from the above catalogues, a database has been compiled on computer format using a rectangular search method for the period from 1808-2008. Critical scrutiny and examination of compiled seismicity data have been carried out and the database was finalized by removing suspected repeated events. The frequency of earthquakes with magnitude and depth of Shillong Plateau is depicted in Table 1. Similarly, the estimated b-value and cutoff magnitude of the region is given in table 2.

Table 1: Frequency of earthquakes with respect to magnitude and focal depth in Shillong Plateau of Northeast India from 1963 to 2008.

\begin{tabular}{|c|c|c|c|c|c|c|c|c|c|}
\hline \multicolumn{9}{|c|}{ Number of earthquakes } & \multirow{3}{*}{$\begin{array}{c}\text { Annual } \\
\text { frequency }\end{array}$} \\
\hline \multirow{2}{*}{\multicolumn{4}{|c|}{ Magnitude $\left(\mathrm{m}_{\mathrm{b}}\right)$}} & \multicolumn{5}{|c|}{ Focal depth (km) } & \\
\hline & & & & \multicolumn{3}{|c|}{ All magnitude } & \multicolumn{2}{|c|}{$\mathrm{m}_{\mathrm{b}} \geq 4.3$} & \\
\hline$\leq 4.2$ & $\geq 4.3$ & $\geq 5.0$ & $\geq 6.0$ & $\leq 40$ & $40-70$ & $>70$ & Shallow & $\begin{array}{l}\text { Inter- } \\
\text { mediate }\end{array}$ & $\mathrm{m}_{\mathrm{b}} \geq 4.3$ \\
\hline 98 & 103 & 22 & -- & 145 & 50 & 6 & 103 & 0 & 2 \\
\hline
\end{tabular}

Table 2: Estimated a \& b-values for Shillong Plateau for the period 1963 to 2008 with cutoff magnitude.

\begin{tabular}{|c|c|c|c|c|}
\hline b-value & a - value & $\mathrm{R}^{2}$ & $\begin{array}{c}\text { Cutoff } \\
\text { Magnitud } \\
\mathrm{e}\end{array}$ & $\begin{array}{c}\text { Area } \\
\left(\times 10^{4} \mathrm{~km}^{2}\right)\end{array}$ \\
\hline \hline $1.27 \pm 0.04$ & $\begin{array}{c}7.58 \pm 0.2 \\
3\end{array}$ & 0.98 & 4.2 & 008.79 \\
\hline
\end{tabular}

Table 3: List of large to great earthquakes for $M \geq 7$ that occurred in Shillong Plateau Northeast India during the period 1897 to 1962 [7] (Gupta et al., 1986).

\begin{tabular}{|c|c|c|r|r|r|r|c|}
\hline \multirow{2}{*}{$\begin{array}{c}\text { Sl. } \\
\text { Nos. }\end{array}$} & Date & Origin Time & \multicolumn{2}{|c|}{ Epicenter } & Depth & M & Source \\
\cline { 2 - 6 } & yyyy mm dd & hh:mm:ss & Long. ${ }^{\circ} \mathrm{E}$ & Lat. ${ }^{\circ} \mathrm{N}$ & $\mathrm{Km}$ & & \\
\hline 1 & 18970612 & $11: 06: 00$ & 91.00 & 26.00 & 60 & 8.7 & OLD \\
\hline 2 & 19180708 & $10: 22: 07$ & 91.00 & 24.50 & 60 & 7.6 & G-R \\
\hline 3 & 19230909 & $22: 03: 43$ & 91.00 & 25.20 & 60 & 7.1 & G-R/BDA \\
\hline 4 & 19300702 & $21: 03: 42$ & 90.00 & 25.50 & 60 & 7.1 & G-R/BDA \\
\hline
\end{tabular}



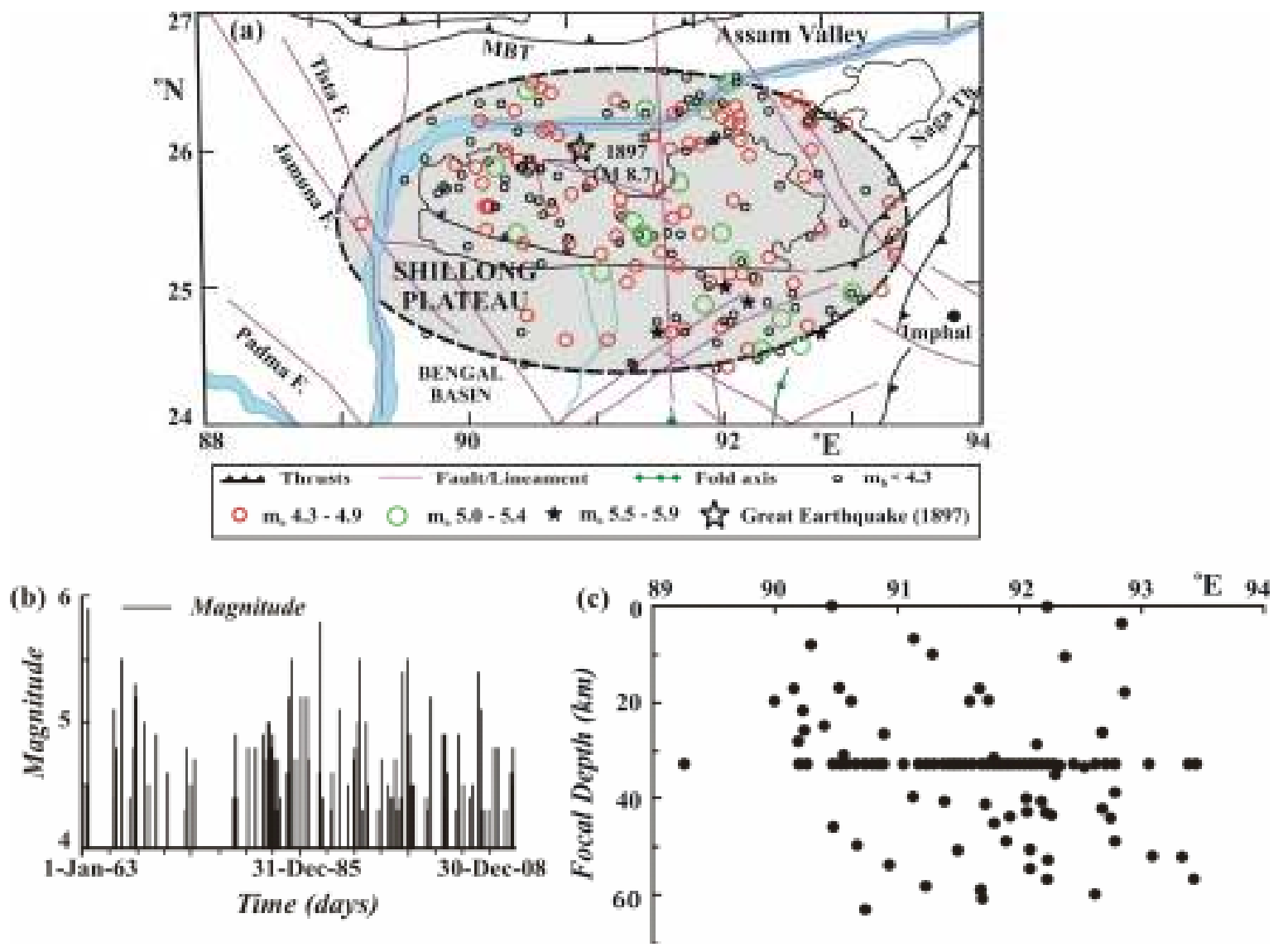

Fig. 1: Patterns of spatial (a), temporal $(b)$ and focal depth (c) distribution of earthquakes $\left(m_{b} \geq 4.3\right)$ in Shillong Plateau region during the period 1963 -2008.

The compiled seismicity data indicates that Shillong plateau region has been mildly active during 19632008. Two prominent seismically active centers can be seen from the spatial distribution of earthquakes shown in Fig. 1a as: a northwest-southeast trending segment measuring approximately $100 \mathrm{~km} \mathrm{x} 350 \mathrm{~km}$ located almost in the middle of the plateau; and the second is of localized nature bounded by $25.5^{\circ}-26.5^{\circ}$ $\mathrm{N} ; 91.7^{\circ}$ E- $93^{\circ}$ E. The larger magnitude earthquakes $\left(m_{b}\right.$ 5.5-5.9) during this period are concentrated to the southeast portion of the plateau near Dauki fault whereas smaller events (M 4.3-5.4) are distributed almost uniformly throughout the plateau. Dauki fault, Dapshi thrust, Kopili fault and Sylhet fault are responsible for earthquake generation in this region. During the period 1963-2008, the total number of events occurred in the region is 201 that includes $40 \%$ events with $\mathrm{m}_{\mathrm{b}} 4.3-4.9$ and $11 \%$ with $\mathrm{m}_{\mathrm{b}} \geq 5.0$ (5.0-5.9) (Table 1). The focal depth distribution of this region is peculiar, where only shallow focus earthquakes have occurred frequently.

Temporal pattern (Fig. 1b) shows extremely low seismic activity up to 1981 followed by a sudden jump in 1982. Although temporal clustering is evident in 1982 (Fig. 1b) but these events are not spatially clustered and distributed widely in plateau region. The seismic activity from 1982 increases constantly but not a single moderate event $\left(\mathrm{m}_{\mathrm{b}} \geq 6.0\right)$ has occurred in the region during the last 46 years. The 
longitude wise focal depth distribution of events shows the higher concentration at depth greater than 30 $\mathrm{km}$ with a clustering of events between $91.7^{\circ}-92.3^{\circ} \mathrm{E}$ (Fig. 1c). It is also observed that about $70 \%$ of larger magnitude earthquakes $\left(\mathrm{m}_{\mathrm{b}} \geq 5.0\right)$ have occurred between the focal depths ranges $30-55 \mathrm{~km}$.

\section{Result and Discussions}

The seismic activity of a region mainly depends upon the subsurface geologic setup and arrangement of tectonic features. The data set has been critically examined for b-values, the spatio-temporal patterns of seismic activity, the focal depth distribution of events in Shillong Plateau. The b- value thus estimated help understanding earthquake occurrence pattern and its relation with other tectonic belts/regions. Thus spatio-temporal distribution of earthquakes and their relationships with the regional/ local geological structures constitute an important field of study for understanding the future seismic hazards and its assessment. The seismic activity in Shillong plateau is confined within the middle portion in two seismically active segments trending northwest-southeast. Temporal pattern shows that the region is due for a great earthquake. The major features of northeast India Himalaya and its adjoining regions is the result of collision tectonics of India and Eurasia. This part of Himalaya is under high compression due to northward movement of Indian plate which is eventually subducting beneath the Eurasian plate. From the interpretation of observed faulting patterns in Shillong plateau, it can be inferred that the region is under compression due to the stresses acting in $\mathrm{N}$ to NE directions. Due to this action, probably the tectonic features of the region are also affected and it is believed that this could be one of the most promising reasons for intense seismic activity in this part of Northeast India.

\section{References}

[1] D. R. Nandy, ABC Publications, Calcutta, (2001).

[2] P. Evans, Journal of Geological Society of India, 5 (1964) 80.

[3] R. Bilham and P. England, Nature, 410 (2001) 806.

[4] S. V. Deshikachar, Journal of Geological Society of India, 15 (1974) 137.

[5] A. N. Tandon and H. N. Srivastava, Ann. Di Geofis., 28 (1975)13.

[6] U. Chandra, Current Science, 62 (1992) 40.

[7] H. K. Gupta, K. Rajendran and H. N. Singh, Journal of Geological Society of India, 28 (1986) 345.

[8] R. D. Oldham, Mem. Geol. Surv. India, 29 (1899) 1.

[9] B. Gutenberg and C. F. Richter, Hafner Publication ( 1954).

[10] M. Bath, and S. Duda, Report No. 1-79, Seismological Institute, Uppsala, Sweden (1979) 41. 